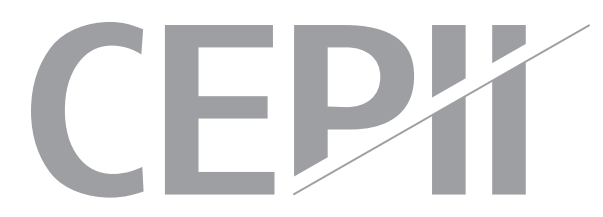

\title{
Immigration and the Gender Wage Gap
}

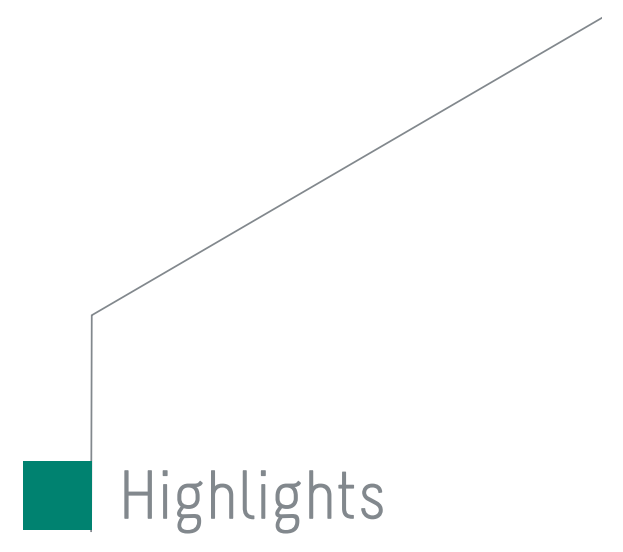

Anthony Edo \& Farid Toubal

I Over the period 1990-2010, immigration to France has disproportionately increased the number of female workers.

- We quantify the elasticity of substitution between male and female workers of similar education and experience and find that they are imperfect substitutes in production.

- We use two complementary empirical methodologies to investigate the effect of immigration on the gender wage gap.

- An immigration-induced increase in the supply of female workers has a negative impact on the relative wage of female natives, thereby contributing to a widening gender wage gap. 


\section{Abstract}

This paper analyzes the effects of immigration on the gender wage gap. Using a detailed individual French dataset, we shed lights on the strong feminization of the immigration workforce from 1990 to 2010. Our theoretical model predicts that a shift in the supply of female workers increases gender wage inequality when men and women are imperfect substitute in production. Our structural estimate shows an imperfect substituability between men and women workers of similar education and experience. Our econometric analysis shows that a $10 \%$ increase in immigrant female labor supply relative to immigrant male labor supply in a given education-experience group lowers the relative earnings of female native workers of that group by $4 \%$. We finally use a structural model to account for the cross-group effects induced by immigration and show that the rise in the relative number of female immigrants has decreased the relative wage of female native workers, thereby contributing to a widening native gender wage gap.

\section{Keywords}

Migration, labor supply, gender wage gap.

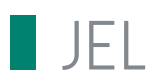

F22, J16, J21, J31, J61.

\section{Working Paper}

\section{CEPI}

CEPII (Centre d'Etudes Prospectives et d'Informations Internationales) is a French institute dedicated to producing independent, policyoriented economic research helpful to understand the international economic environment and challenges in the areas of trade policy, competitiveness, macroeconomics, international finance and growth.
CEPII Working Paper

Contributing to research in international economics

(C) CEPII, PARIS, 2015

All rights reserved. Opinions expressed in this publication are those of the author(s) alone.

$\begin{array}{ll}\text { Editorial Director: } & \text { CEPII } \\ \text { Sébastien Jean } & \text { 113, rue de Grenelle } \\ & 75007 \text { Paris } \\ \text { Production: } & +33153685500 \\ \text { Laure Boivin } & \text { www.cepii.fr } \\ \text { No ISSN: } 1293-2574 & \text { Press contact: presse }\end{array}$




\title{
Immigration and the Gender Wage Gap ${ }^{1}$
}

\author{
Anthony Edo ${ }^{2} \&$ Farid Toubal ${ }^{3}$
}

\section{Introduction}

An extensive literature in social sciences and economics has searched for the driving force behind the gender wage gap. This gap is often related to differences in productivity and discrimination between men and women (Altonji and Blank, 1999; Blau and Kahn, 2000; Goldin, 2014) and also to the role of the feminization of the labor workforce (Topel, 1997; Juhn and Kim, 1999; Acemoglu, Autor, and Lyle, 2004). ${ }^{4}$ Surprisingly, the role of immigration has received less attention. It is however a potential important factor as the feminization of the immigration labor force has been one of the most significant trends in the recent years according to the United Nations Population Division (2013). ${ }^{5}$

The increasing proportion of employment-related migrants is particularly important in France, where the share of women in the immigrant labor force has increased from $34 \%$ in 1990 to $47 \%$ in $2010 .{ }^{6}$ The feminization of the immigration workforce might have an impact on the wages of female and male native workers and therefore on the gender wage gap.

We explore this question by using a rich dataset taken from the French labor survey that covers the period from 1990 to 2010 . The dataset provides enough detailed information to investigate the impact of immigration on native wages along different important dimensions. In particular, it contains precise information on the educational attainment of natives and immigrants as well as information on their gender, age and occupation.

\footnotetext{
${ }^{1}$ We wish to thank Michel Beine, Isabelle Bensidoun, Frédéric Docquier, Gabriel Felbermayr, Lionel Fontagné, Sébastien Jean, Mariapia Mendola, Gianmarco Ottaviano, Hillel Rapoport as well as the workshop participant of the 6th International Conference on Economics and Global Interactions for helpful comments. We are grateful to the Centre Maurice Halbwachs $(\mathrm{CMH})$ for having granted us access to the data set. Financial support was provided by the iCODE Institute (Idex ParisSaclay). Any errors which remain are our own.

${ }^{2}$ CEPII, France. E-mail: Anthony.Edo@cepii.fr.

${ }^{3}$ ENS de Cachan, Paris School of Economics, CEPII, France. E-mail: ftoubal@ens-cachan.fr.

${ }^{4}$ In a very interesting study, Acemoglu, Autor, and Lyle (2004) show, for instance, that the supply shift induced by the rapid rise in female labor force participation after World War II has mainly contributed to reduce female wages, thus increasing the gender wage gap.

${ }^{5}$ The United Nations Population Division (2013) reports that about half of the total number of migrants around the world are women. There are few articles investigating the feminization of the migration population, see for e.g. the interesting contributions of Zlotnik (1995); Marcelli and Cornelius (2001); Omelaniuk (2005); Docquier, Lowell, and Marfouk (2009); Docquier, Marfouk, Salomone, and Sekkat (2012).

${ }^{6}$ More specifically, we find an increase in the share of female immigrants with higher education. In an recent study, Docquier, Lowell, and Marfouk (2009) examine the skill composition of female migrants. Using the same period of investigation, they find that women represent an increasing share of the OECD immigration stock and exhibit relatively higher skilled emigration rates than men.
} 
We document significant differences in the pattern of occupation across male and female immigrant workers who share similar education - female immigrants are concentrated in few occupations such as administrative jobs. We also find that occupational differences by gender is more important than occupational differences by nativity status. ${ }^{7}$ These last facts may suggest an imperfect substitutability between men and women within each education group.

We develop a model that takes into account the possibility of a substitution between male and female workers. In case of an imperfect substitutability between men and women, immigration should impact wages of male and female differently (Topel, 1997). Given (i) the strong feminization of the immigration workforce and (ii) the imperfect substitutability between men and women, immigration should increase the relative wage of male native workers. Using different samples and methodologies, our results indicate an imperfect substitution between men and women workers with similar education and experience. ${ }^{8}$ This result is consistent with Acemoglu, Autor, and Lyle (2004) for the U.S. who find that men and women with similar state of residence are imperfect substitutes in production.

We find that an immigration-induced increase in the supply of female workers has a negative impact on the relative wage of female native workers. This finding is robust using two complementary empirical methodologies. On the one hand, we analyze the effect of the relative increase in the supply of female immigrants on the relative wage of female native workers within the same education-experience group. This econometric analysis which examines the "within-group" effects of immigration shows a negative impact that is robust to the implementation of an instrumental variable (IV) strategy. On the other hand, we use a structural approach to analyze the overall impact of immigration on the wages of female and male native workers. This methodology allows us to take into account the impact of immigrants that are not competing in the same group than native workers (Borjas, 2003; Manacorda, Manning, and Wadsworth, 2012; Ottaviano and Peri, 2012). We find a negative effect of the relative increase in the supply of women due to immigration on the wages of women native workers, thereby contributing to a widening gender wage gap.

This article contributes to the immigration literature in several respects. The literature on labor market gender gap documents the differences in jobs and wages between women and men of similar

\footnotetext{
${ }^{7}$ Similar results are found in the literature (Anker et al., 1998; Blau, Ferber, and Winkler, 2002; Dustmann, Frattini, and Preston, 2007).

${ }^{8}$ This might be due to difference in preferences as in Croson and Gneezy (2009). They identify strong gender differences in attitudes and behaviors, aversion to competition and overconfidence. These differences in productive characteristics might explain the preference of some employers for the employment of men or women workers in different jobs or tasks. Also, men and women of similar education may differ in terms of their physical and relational skills, leading (i) men to be overrepresented in manual occupation as found by Sikora and Pokropek (2011) and (ii) women to perform jobs related to services and social interactions (Charles and Grusky, 2005). Many other factors, ranging from outright discrimination, to the processes associated with gender role socialization may lead to different choices of occupation between men and women (Eccles, 1994).
} 
education (Anker et al., 1998; Blau and Kahn, 2000; Goldin, 2014). However, it does not quantify the elasticity of substitution between male and female workers of similar education and experience. ${ }^{9}$ We set out a methodology and provide a structural estimate of the elasticity of substitution between male and female workers within the same education and experience group.

While structural methods have been widely applied to samples from different countries, none of the papers use them to investigate the impact of immigration on the relative wage of female native workers. ${ }^{10}$ Our model which also incorporates wage rigidities as in D'Amuri, Ottaviano, and Peri (2010) to account for the sluggish adjustment of the French labor market, offers new predictions concerning the effect of immigration on the gender wage gap.

The paper also contributes to a different strand of the literature that focuses on the effect of female migration. While most of the papers examine the effect of female migration on employment or job specialization of native female workers, none have examined the differential impact of immigration on the wages of female and male native workers. ${ }^{11}$ The literature on the impact of migrants on wage or employment focuses mostly on male workers.

The remainder of this paper proceeds as follows. In section 2, we describe the theoretical framework used to simulate the overall effects of immigration on wages. In section 3 , we describe the data. The section 4 provides our estimates regarding the elasticity of substitution between men and women and it discusses our choices for the other substitution elasticity values. In section 5 , we first provide a regression analysis on the "within-group" impact of women and men immigrants on the relative wage of native women. We then impose our theoretical structure to simulate our model. The last section concludes.

\section{Theoretical Framework}

This paper uses the traditional "structural skill-cell approach" to evaluate the full wage response of natives to immigration. This method has been widely used to study the wage response to labor supply and demand shocks at the national level (Katz and Murphy, 1992; Card and Lemieux, 2001; Borjas, 2003; Ottaviano

\footnotetext{
${ }^{9}$ Acemoglu, Autor, and Lyle (2004) provide an estimate of the elasticity of substitution between men and women but at the region level. In this paper, we estimate the degree of substitution between men and women at the education-experience level.

${ }^{10}$ see, e.g., Aydemir and Borjas (2007); Borjas and Katz (2007); Ottaviano and Peri (2012) for the United states, D'Amuri, Ottaviano, and Peri (2010); Felbermayr, Geis, and Kohler (2010); Brücker and Jahn (2011) for Germany, Gerfin and Kaiser (2010) for Switzerland, Manacorda, Manning, and Wadsworth (2012) for the United Kingdom, Edo and Toubal (2015) for France, as well as Docquier, Ozden, and Peri (2013) for OECD countries or Elsner (2013) on the emigration wage effect in Great Britain.

${ }^{11}$ Cortes (2008); Barone and Mocetti (2011); Cortes and Tessada (2011); Farré, González, and Ortega (2011) study the effect of female immigration on the price levels or female labor supply. Amuedo-Dorantes and De La Rica (2011) investigate the impact of immigration on tasks specialization by gender in Spain. Forlani, Lodigiani, and Mendolicchio (2015) examine the effect of low skilled immigration on female native immigrants in the household sectors.
} 
and Peri, 2012). It allows to investigate the overall impact of immigration on native wages, inasmuch this structural approach does "not simply estimate the own-effect of a particular immigrant influx on the wage of directly competing native workers, but also the cross-effects on the wage of other native workers" (Borjas (2014), p. 106). We extend this approach by taking into account the substitutability between men and women workers.

The nested CES structure. The "structural skill-cell approach" is based on an aggregate production function with a nested CES structure of labor (e.g., see Borjas (2003); Manacorda, Manning, and Wadsworth (2012); Ottaviano and Peri (2012)). We assume a constant-return-to-scale aggregate production function that takes the Cobb-Douglas form (D'Amuri, Ottaviano, and Peri, 2010; Brücker and Jahn, 2011; Ottaviano and Peri, 2012). This assumption allows us to concentrate exclusively on the long-run effects of immigration on wages, by considering full capital adjustment as a response to immigrant-induced labor supply shifts.

The aggregate production function is given by Equation (1). The physical capital $K_{t}$ and a labor composite $L_{t}$ are combined to produce output $Y_{t}$ at time $t$.

$$
Y_{t}=A_{t} \cdot K_{t}^{1-\alpha} \cdot L_{t}^{\alpha}
$$

where $A_{t}$ is exogenous total factor productivity (TFP) and $\alpha \in(0,1)$ is the income share of labor. $L_{t}$ is defined as a composite of different categories of workers who have different level of education, work experience and nativity. We follow the literature on the wage structure (Katz and Murphy, 1992; Autor, Katz, and Kearney, 2008; Goldin and Katz, 2009) or on migration (Card and Lemieux, 2001; Card, 2009; Ottaviano and Peri, 2012) by assuming $L_{t}$ to have a nested CES structure, which combines the labor supply of two broad education groups $b \in\{H, L\} . L_{H t}$ and $L_{L t}$ are aggregate measures of the labor supply of high and low educated workers, respectively.

$$
L_{t}=\left[\theta_{H t} \cdot L_{H t}^{\rho_{H L}}+\theta_{L t} \cdot L_{L t}^{\rho_{H L}}\right]^{1 / \rho_{H L}}
$$

The parameters $\theta_{H t}$ and $\theta_{L t}$ measure the relative efficiency of each category, with $\theta_{H t}+\theta_{L t}=1$. $\rho_{H L}=\left(\sigma_{H L}-1\right) / \sigma_{H L}$ with $\sigma_{H L}$ being the degree of substitution between the group of high educated workers and the group of low educated workers.

The education groups $L_{H t}$ and $L_{L t}$ respectively refer to an education level beyond high school and less than college. Implicitly, this classification assumes that within these two large groups, workers with 
different levels of education are perfect substitutes. The classification proposed by Card $(2009,2012)$ that uses two main education groups might be too restrictive given our sample. As a result, we split up $L_{H t}$ and $L_{L t}$ into two finer education groups $j \in\{1,2\}$ as follows:

$$
\begin{aligned}
L_{H t} & =\left[\theta_{H_{1} t} \cdot L_{H_{1} t}^{\rho_{H}}+\theta_{H_{2} t} \cdot L_{H_{2} t}^{\rho_{H}}\right]^{1 / \rho_{H}} \\
L_{L t} & =\left[\theta_{L_{1} t} \cdot L_{L_{1} t}^{\rho_{L}}+\theta_{L_{2} t} \cdot L_{L_{2} t}^{\rho_{L}}\right]^{1 / \rho_{L}}
\end{aligned}
$$

where $\rho_{H}=\left(\sigma_{H}-1\right) / \sigma_{H}$ and $\rho_{L}=\left(\sigma_{L}-1\right) / \sigma_{L}$, with $\sigma_{H}$ and $\sigma_{L}$ capture the degree of substitution between workers within each broad education groups. The terms $L_{b j t}$ for $b j \in\left\{H_{1}, H_{2}, L_{1}, L_{2}\right\}$ are aggregate measures of labor supplied by workers with, respectively, some college education $\left(H_{1}\right)$, a college degree $\left(H_{2}\right)$, less than high school education $\left(L_{1}\right)$ and a high school education $\left(L_{2}\right)$. For ease of clarification, we note $\sigma_{b} \in\left\{\sigma_{H}, \sigma_{L}\right\}$. The parameters $\theta$ are the education specific productivity levels with $\theta_{H_{1} t}+\theta_{H_{2} t}=1$ and $\theta_{L_{1} t}+\theta_{L_{2} t}=1$.

As shown by Edo and Toubal (2015), the education group $L_{H t}$ in France represents $25 \%$ of the total number of workers and is composed of homogeneous individuals - i.e., the workers with some college $\left(L_{H_{1} t}\right)$ or a college degree $\left(L_{H_{2} t}\right)$ are perfect substitutes in production. As a result, we consider that $\sigma_{H} \rightarrow \infty .^{12}$ However, within the group of low educated workers, ${ }^{13}$ Edo and Toubal (2015) find that workers with high school education $\left(L_{2}\right)$ and less than a high school education $\left(L_{1}\right)$ are imperfect substitutes (with an elasticity of substitution equals to 10 ). We thus keep the decomposition of the low educated group $L_{L t}$ into two finer education classes, denoted $L_{L_{1} t}$ and $L_{L_{2} t}$. ${ }^{14}$ As a result, we use two broad education groups $b \in\{H, L\}$, and three education classes grouping together workers with tertiary education $L_{H t}$, secondary education $L_{L_{2} t}$ and primary education - where $L_{b j t} \in\left\{L_{L_{1} t}, L_{L_{2} t}, L_{H t}\right\}$. ${ }^{15}$

Considering the experience level of workers, we divide the labor composite $L_{b j t}$ into four experience intervals of five years [1-10; 10-20; 20-30; 30-40], as in Felbermayr, Geis, and Kohler (2010); Gerfin and Kaiser (2010); Elsner (2013); Brücker, Hauptmann, Jahn, and Upward (2014). This strategy has three

\footnotetext{
${ }^{12}$ This follows Card and Lemieux (2001); Card (2009). For the United States, they do not disaggregate the high education group corresponding to college equivalent workers.

${ }^{13}$ The low educated category $L_{L t}$ regroups $75 \%$ of workers, among which $62.6 \%$ have a high school degree and $37.4 \%$ have an education below high school (Edo and Toubal, 2015).

${ }^{14}$ This disaggregation is consistent with Goldin and Katz (2009); Borjas, Grogger, and Hanson (2012); Ottaviano and Peri (2012).

${ }^{15}$ D'Amuri, Ottaviano, and Peri (2010); Gerfin and Kaiser (2010); Elsner (2013) also use three education classes to investigate the wage impact of migration in Germany, Switzerland and Lithuania, respectively. In addition, our classification using three education groups is consistent with the study by Brücker, Hauptmann, Jahn, and Upward, (2014, p. 211) which shows that "it is most suitable to distinguish three education groups in European labor markets."
} 
main advantages. First, it attenuates the impact of any potential bias regarding our experience measure, and in particular, the fact that employers may evaluate the experience of immigrants differently than natives. Second, by increasing the number of observation per cell, our strategy with 12 skill-cells (three education groups and four experience groups) tends to correct for the attenuation bias our estimates may suffer (Aydemir and Borjas, 2011). Third, since women tend to face more frequent periods of inactivity or unemployment, the correspondence between their potential and effective experience may collapse. It is therefore relevant to use four but broader experience groups to study the labor market effects of immigration on male and female natives.

$$
L_{b j t}=\left[\sum_{k=1}^{4} \theta_{b j k t} \cdot L_{b j k t}^{\rho_{X}}\right]^{1 / \rho_{X}}
$$

$L_{b j k t}$ is the number of workers with education $b j$ and experience $k$ at time $t$. We define $\rho_{X}=$ $\left(\sigma_{X}-1\right) / \sigma_{X}$, where $\sigma_{X}$ measures the elasticity of substitution across the different experience classes and within a narrow education group. The parameters $\theta_{b j k t}$ capture the relative efficiency of workers within the education-experience group.

We allow males and females to be imperfect substitutes. As men and women work in different jobs (Anker et al., 1998; Blau, Ferber, and Winkler, 2002), they may not compete in the same labor market. One reason behind this labor market segmentation may lie in important gender differences in attitudes and behaviors, aversion to competition, overconfidence (Croson and Gneezy, 2009) and other types of productive characteristics. We thus assume that $L_{b j k t}$ incorporates contributions of workers who differ in gender, and we divide $L_{b j k t}$ into a CES aggregator of males and females as follows:

$$
L_{b j k t}=\left[\theta_{S_{M} b j k t} \cdot \text { Male }_{b j k t}^{\rho_{F}}+\theta_{S_{F} b j k t} \cdot \text { Female }_{b j k t}^{\rho_{F}}\right]^{1 / \rho_{F}}
$$

where $\rho_{F}=\left(\sigma_{F}-1\right) / \sigma_{F}$ and $\sigma_{F}$ denotes the elasticity of substitution between men and women, while $\theta_{S_{M} b j k t}$ and $\theta_{S_{F} b j k t}$ stand for their specific efficiency levels standardized so that $\theta_{S_{M} b j k t}+\theta_{S_{F} b j k t}=$ 1.

Turning to the nativity of workers, we follow Manacorda, Manning, and Wadsworth (2012); Ottaviano and Peri (2012) and assume $L_{S b j k t}$ to be a CES aggregate of native-born $N_{S b j k t}$ and of foreign-born workers $M_{S b j k t}$ :

$$
L_{S b j k t}=\left[\theta_{S b j k t}^{N} \cdot N_{S b j k t}^{\rho_{I}}+\theta_{S b j k t}^{M} \cdot M_{S b j k t}^{\rho_{I}}\right]^{1 / \rho_{I}}
$$


where $\rho_{I}=\left(\sigma_{I}-1\right) / \sigma_{I}$ and $\sigma_{I}$ captures the degree of substitution between natives and immigrants in an education-experience cell. The relative efficiency for each group of workers is given by the productivity parameters $\theta_{S b j k t}^{N}$ and $\theta_{S b j k t}^{M}$, with $\theta_{S b j k t}^{N}+\theta_{S b j k t}^{M}=1$.

Introducing wage rigidities. The nested CES framework allows to compute the overall impact of immigration under the assumption that wages adjust perfectly to labor supply shocks. However, the French labor market characterized by high minimum wage, high unemployment benefits, strict employment protection and powerful labor unions may prevent full wage adjustment. These dimensions should affect the wage-setting mechanism (Babeckỳ, Du Caju, Kosma, Lawless, Messina, and Rõõm, 2010), the reservation wage (Cohen, Lefranc, and Saint-Paul, 1997) and the scope for bargaining, which in turn should have an impact on the responsiveness of wages to labor supply shocks (as suggested by D'Amuri, Ottaviano, and Peri (2010); Felbermayr, Geis, and Kohler (2010); Brücker and Jahn (2011); Brücker, Hauptmann, Jahn, and Upward (2014)). ${ }^{16}$ For France, Edo (2015) also finds that immigration has no detrimental effect on the native wage structure, whereas it positively affects the level of native unemployment in the short-run.

As a result, wages should not adjust perfectly to immigrant-induced supply shifts in France. We thus extend the structural approach by accounting for wage rigidities, as in D'Amuri, Ottaviano, and Peri (2010). ${ }^{17}$ In their model, they assume that "a change in wages [produced by immigration] may induce an employment response for natives" (D'Amuri, Ottaviano, and Peri (2010), p. 553). In this model, natives respond to wage changes because of the prevalence of high unemployment benefits. As a result, immigration should induce (i) a direct wage effect due to immigrant-induced supply shifts and (ii) an indirect wage effect through native employment response. In this model, the indirect wage effects thus attenuate the direct wage effects induced by immigration, allowing for a sluggish adjustment of wages. In order to compute the employment effects (or the indirect wage effects) due to immigration, we use the strategy by D'Amuri, Ottaviano, and Peri (2010) and we follow Edo and Toubal (2015) who assume that for an increase in immigrants equals to $1 \%$ of the education-experience cell employment, native employment decreases by $3 \%{ }^{18}$

Labor market equilibrium. In equilibrium, wages (and employment) levels are such that firms maximize profits. Profit-maximizing firms pay each skill group a real wage equal to the group's marginal product. By equating native wage to the marginal products of their labor $\left(w_{S b j k t}^{N}=\delta Y_{t} / \delta N_{S b j k t}\right)$ and using Equations (1) to (7), we can derive an expression for the equilibrium wage of natives for each gender-

\footnotetext{
${ }^{16}$ This is also consistent with Card, Kramarz, and Lemieux (1999) who show that labor supply shocks have less impact on the adjustment of wages in France because of wage rigidities.

${ }^{17}$ See also Edo and Toubal (2015) for more details.

${ }^{18}$ This magnitude is found by Glitz (2012) for Germany and Edo (2015) for France.
} 
education-age-time cell:

$$
\begin{aligned}
\log \left(w_{\text {Sbjkt }}^{N}\right)= & \log \left(\alpha \cdot A_{t} \cdot\left[\kappa_{t}\right]^{1-\alpha}\right)+\frac{1}{\sigma_{H L}} \cdot \log \left(L_{t}\right)+\log \left(\theta_{b t}\right)-\left[\frac{1}{\sigma_{H L}}-\frac{1}{\sigma_{b}}\right] \log \left(L_{b t}\right) \\
& +\log \left(\theta_{b j t}\right)-\left[\frac{1}{\sigma_{b}}-\frac{1}{\sigma_{X}}\right] \log \left(L_{b j t}\right)+\log \left(\theta_{b j k t}\right)-\left[\frac{1}{\sigma_{X}}-\frac{1}{\sigma_{I}}\right] \log \left(L_{b j k t}\right) \\
& +\log \left(\theta_{\text {Sbjkt }}\right)-\frac{1}{\sigma_{F}} \cdot \log \left(L_{S b j k t}\right)+\log \left(\theta_{\text {Sbjkt }}^{N}\right)-\frac{1}{\sigma_{I}} \cdot \log \left(N_{\text {Sbjkt }}\right)
\end{aligned}
$$

$\kappa_{t}=\left(K_{t} / L_{t}\right)$ and the productivity parameters $\theta$ measure the specific productivity levels between workers with different education, experience, gender and nativity. $\sigma_{H L}, \sigma_{b}, \sigma_{X}, \sigma_{F}$ and $\sigma_{I}$ respectively measure the elasticities of substitution between the high and low education groups, within both broad education groups, between experience groups, between men and women and between natives and immigrants.

Any changes in one of the factors on the right-hand side affect the marginal product, which leads to a change in the real wage ceteris paribus. According to Equation (8), an immigration-induced supply shift in a given skill group $S, b j$, and $k$ thus generates a (potentially negative) partial effect on the wages of native workers in the same gender-education-experience group, as well as (potentially positive) cross-effects on the wages of natives in other groups.

Wage effects of immigration. The overall impact of immigration on native wages can be derived from the demand function (8). As in Borjas (2003); Ottaviano and Peri (2012), the TFP and productivity levels are assumed to be insensitive to immigration. Thus, we can express the percentage wage changes due to immigrants for natives in the long-run as:

$$
\begin{aligned}
\left(\frac{\triangle w_{b j k t}^{N}}{w_{b j k t}^{N}}\right)= & {\left[\frac{1}{\sigma_{H L}}\right] \sum_{b} \sum_{j} \sum_{k} \sum_{S}\left(s_{S b j k t}^{M} \cdot \frac{\triangle M_{\text {Sbjkt }}}{M_{\text {Sbjkt }}}+s_{\text {Sbjkt }}^{N}\left(\frac{\triangle N_{\text {Sbjkt }}}{N_{\text {Sbjkt }}}\right)_{\text {response }}\right) } \\
& -\left[\frac{1}{\sigma_{H L}}-\frac{1}{\sigma_{b}}\right]\left(\frac{1}{s_{b t}}\right) \sum_{j} \sum_{k} \sum_{S}\left(s_{\text {Sbjkt }}^{M} \cdot \frac{\triangle M_{S b j k t}}{M_{S b j k t}}+s_{S b j k t}^{N}\left(\frac{\triangle N_{\text {Sbjkt }}}{N_{\text {Sbjkt }}}\right)_{\text {response }}\right) \\
& -\left[\frac{1}{\sigma_{b}}-\frac{1}{\sigma_{X}}\right]\left(\frac{1}{s_{b j t}}\right) \sum_{k} \sum_{S}\left(s_{S b j k t}^{M} \cdot \frac{\triangle M_{S b j k t}}{M_{S b j k t}}+s_{\text {Sbjkt }}^{N}\left(\frac{\triangle N_{\text {Sbjkt }}}{N_{\text {Sbjkt }}}\right)_{\text {response }}\right) \\
& -\left[\frac{1}{\sigma_{X}}-\frac{1}{\sigma_{F}}\right]\left(\frac{1}{s_{b j k t}}\right) \sum_{S}\left(s_{S b j k t}^{M} \cdot \frac{\triangle M_{b j k t}}{M_{b j k t}}+s_{S b j k t}^{N}\left(\frac{\triangle N_{\text {Sbjkt }}}{N_{\text {Sbjkt }}}\right)_{\text {response }}\right)
\end{aligned}
$$




$$
\begin{aligned}
& -\left[\frac{1}{\sigma_{F}}-\frac{1}{\sigma_{I}}\right]\left(\frac{1}{s_{S b j k t}}\right)\left(s_{S b j k t}^{M} \cdot \frac{\triangle M_{S b j k t}}{M_{S b j k t}}+s_{S b j k t}^{N}\left(\frac{\triangle N_{S b j k t}}{N_{S b j k t}}\right)_{\text {response }}\right) \\
& -\left[\frac{1}{\sigma_{I}}\right]\left(\frac{\triangle N_{S b j k t}}{N_{S b j k t}}\right)_{\text {response }}+(1-\alpha)\left(\frac{\triangle \kappa_{t}}{\kappa_{t}}\right)
\end{aligned}
$$

where $s_{b t}, s_{b j t}, s_{b j k t}, s_{S b j k t}, s_{S b j k t}^{M}$ and $s_{S b j k t}^{N}$ are the shares of the total wage income paid to the respective groups. ${ }^{19}$ The terms $\left(\triangle M_{S b j k t} / M_{S b j k t}\right)$ and $\left(\triangle N_{S b j k t} / N_{S b j k t}\right)_{\text {response }}$ are the changes in immigrant and native labor supply in the same respective groups over the corresponding period.

The fraction $\left(\triangle M_{S b j k t} / M_{S b j k t}\right)$ represents the percentage change in the supply of immigrant workers with gender $S$, education $b j$ and experience $k$ between 1990 and 2010. The terms capture the direct effect of the change in the supply of immigrants on wages. The terms associated with the subscript "response" account for employment effects caused by the change in the supply of immigrant workers in a given skill-cell - i.e., $\left(\triangle N_{S b j k t} / N_{S b j k t}\right)_{\text {response }}$ represents the change in labor supply of native workers in the same group caused by immigration. These terms capture the indirect wage effects due to the change in native employment caused by immigrants. As a result, the percentage wage changes due to immigration depends on (i) the income shares accruing to the various factors, (ii) both direct and indirect wage effects depending on the size of the immigration supply shock and (iii) the various elasticities of substitution that lie at the core of the CES framework.

As in D'Amuri, Ottaviano, and Peri (2010), the response of native employment in the cell $(S, b, j, k, t)$ is obtained by multiplying 0.7 by the change in immigrants standardized by the initial employment - i.e. $\left(\triangle M_{S b j k t} / M_{S b j k t}+N_{S b j k t}\right)$. This strategy assumes that the displacement effects due to immigration are similar across cells. Section 5 discusses the implications of this assumption.

Using the percentage change in wages for each cell $(S, b, j, k, t)$, we can then aggregate and find the effect of immigration on several representative wages. From Equation (9), we can calculate the mean wage effect of immigration for the various education groups by taking the weighted average of the wage effects across the experience groups for a particular education group. The weights are given by income shares. By taking the weighted average of the wage effects across education groups, we can compute the total wage effects due to immigration.

\footnotetext{
${ }^{19}$ For instance, $s_{S b j k t}^{M}=\left(w_{S b j k t}^{M} M_{S b j k t}\right) / \sum_{b} \sum_{j} \sum_{k} \sum_{S}\left(w_{S b j k t}^{M} M_{S b j k t}+w_{S b j k t}^{N} N_{S b j k t}\right)$ is the share of total wage income in period $t$ paid to migrant workers with with gender $S$, education $b j$ and experience $k$.
} 


\section{Data and Facts}

Sample and variables. The analysis uses data from the French annual labor force survey (LFS) which covers 21 years of individual-level data for the period 1990 to 2010. The LFS is conducted by the French National Institute for Statistics and Economic Studies (INSEE). ${ }^{20}$ It provides detailed information on demographic and social characteristics at the individual level. Our data are composed of two distinct waves that we merge together. The first wave of data (1990-2002) covers a random sample of around 145,000 individuals per year, with a sampling rate equal to $0.35 \%$. The second wave of data (2003-2010) covers a random sample of around 295,000 individuals per year, the sampling rate is equal to $0.65 \%$.

In order to make our sample representative of the French population, we systematically use an individual weight (computed by the INSEE). This weight indicates the number of individuals each observation represents in the total population. ${ }^{21}$

Our empirical analysis uses information on individuals aged from 16 to 64 . We follow several studies on immigration and we drop all individuals who are self-employed (such as farmers, business owners, liberal professions), in military occupations or enrolled at school (Borjas, 2003, 2006; Ottaviano and Peri, 2012). We also exclude all persons in the clergy since the wage-setting mechanism in that occupation should differ from the wage-setting of all other workers.

We define an immigrant as a person born outside France and who is either a noncitizen or a naturalized citizen. All other individuals are considered as natives. This definition is similar to (Borjas, 2003, 2006; Ottaviano and Peri, 2012). In this paper, we use the terms immigrant and foreign-born interchangeably.

The employment survey divides the education level into six categories: college graduate, some college, high school graduate, some high school, just before high school, no education. According to the International Standard Classification of Education (ISCED), those levels of education respectively correspond to (1) a second stage of tertiary education, (2) first stage of tertiary education, (3) post-secondary nontertiary education, (4) (upper) secondary education, (5) lower secondary education and (6) a primary or pre-primary education. In order to classify the workers in terms of their level of education, we merge the two highest education groups (1) \& (2) to build the group $L_{H}$, the two medium (3) \& (4) and the two lowest (5) \& (6) to build $L_{L_{2}}$ and $L_{L_{1}}$, respectively.

Individuals with the same level of education, but a different age or experience are unlikely to be perfect substitutes (Card and Lemieux, 2001). Hence, individuals are characterized by their labor market experience. Following Mincer (1974), work experience is computed by subtracting for each individual the age of schooling completion from reported age. This measure differs from the one used in the migration

\footnotetext{
${ }^{20}$ Institut National de la Statistique et des Etudes Economiques.

${ }^{21}$ The weight is called "extri". For the period 2003-2010, we follow the suggestion by the INSEE and we use "extri16" as weight to compute average wage by skill group.
} 
literature since the age of completion of schooling is usually unavailable. ${ }^{22}$ For a few surveyed individuals, the age of completion of schooling is very low, between 0 and 11 inclusive. Since individuals cannot start accumulating experience when they are too young, we have raised the age of completion of schooling for each surveyed individual to 12 if it is lower. We restrict the analysis to persons who have between 1 and 40 years of experience

The survey reports for each worker the monthly wage net of employee payroll tax contributions adjusted for non response, as well as the usual number of hours worked a week. ${ }^{23}$ Since wages are reported in nominal terms, we deflate the data using the French Consumer Price Index provided by the INSEE. Based on monthly wages and hours worked, we compute the mean log hourly wage as a proxy for the price of labor at the skill-cell level. In the empirical analysis, we use two wage measures (monthly and hourly) to estimate the elasticity of substitution between men and women, as well as between natives and immigrants.

In order to compute the substitution elasticities and to simulate our model, we need a proxy for labor supply in each skill group. From a theoretical point of view, the labor quantity in a specific cell stands for the number of "efficiency units" provided by all workers. Following Borjas, Grogger, and Hanson (2008, 2011); D'Amuri, Ottaviano, and Peri (2010), we express labor supply as the level of employment in a specific cell. This strategy is also consistent with Manacorda, Manning, and Wadsworth (2012) who use population as a measure of labor supply.

The gender distribution of immigrants over time. In France, the stock of female immigrants has grown proportionally faster than the stock of male immigrants. In this regard, Figure 1 shows that the share of female immigrant workers in France has increased more than the share of male immigrant workers, going from $34 \%$ of the immigrant labor force in 1990 to $47 \%$ in 2010.

Since 2008 , women immigrants represent $51 \%$ of the total immigrant population in France (Beauchemin, Borrel, and Régnard, 2013). The share of female immigrants in the total labor force has doubled, increasing from $2.3 \%$ in 1990 to $4.3 \%$ in 2010 , while the share of male immigrants only increased from $4.5 \%$ to $4.9 \%{ }^{24}$

\section{- Insert Figure 1 about here -}

\footnotetext{
${ }^{22}$ Empirical works rather assign a particular entry age into the labor market to the corresponding educational category.

${ }^{23}$ For the period 1990-2002, we use the number of hours worked during the previous week for those workers who do not have regular and fixed hours worked.

${ }^{24}$ In terms of workforce participation, the share of female immigrants in the female labor force went from $5 \%$ to $9 \%$, while the share of male immigrants in the male labor force went from $8 \%$ to $10 \%$.
} 
The educational distribution of natives and immigrants by gender. Table 1 shows the educational composition of natives and immigrants in the labor force by gender groups. For both males and females, we display the fraction of natives and foreign-born in the labor force for the high, medium and low education categories in 1990 and 2010. Table 1 shows that the labor force becomes increasingly educated over time. In particular, the table illustrates the rapid increase of the fraction of immigrants in the highly educated category (with some college or more). Irrespective of gender, about $28 \%$ of immigrants are classified as highly educated, against less than $10 \%$ in 1990 . However, the growth in high educated labor force is faster for immigrants than for native workers. This partly reflects the shift toward a migration policy which is more selective (Edo and Toubal, 2015). Among the population of immigrants, the educational shift is more pronounced for women than for men workers.

- Insert Table 1 about here -

Gender, migration and occupation. In Table 2, we report the average share of workers according to their gender and origin by occupation. We group workers into five broad occupation categories defined according to the socio-professional categorization of INSEE. The table reports first strong differences in occupation by gender (as in e.g., Anker et al. (1998); Blau, Ferber, and Winkler (2002); Jurajda (2003); Collado, Iturbe-Ormaetxe, and Valera (2004)). While female workers constitute more than 50\% of administrative workers, male workers represents less than $15 \%$ of this socio-professional category. Male workers are concentrated in skilled and unskilled manual occupations. This finding are in line with Dustmann, Frattini, and Preston (2007) that show a disproportionate concentration of women in intermediate non-manual occupations and in personal services in the United Kingdom. Sikora and Pokropek (2011) also show that women are leading men in their interest in non-manual occupations in almost all countries.

- Insert Table 2 about here -

We also find that immigrants tend to be concentrated in skilled and unskilled manual jobs as compared to natives. Using data on immigration in the United Kingdom, Dustmann, Frattini, and Preston (2013) find a stronger concentration of immigrants in unskilled jobs. Importantly, Table 2 indicates that the occupational differences are more important between men and women than between natives and immigrants. Similar results are found for the United Kingdom (Dustmann, Frattini, and Preston, 2007) and Spain (Amuedo-Dorantes and De La Rica, 2011). ${ }^{25}$

\footnotetext{
${ }^{25}$ It is also documented that occupational segregation by gender in the United States was more important than occupational segregation by race or ethnicity (Blau, Ferber, and Winkler, 2002).
} 
In Table 3, we cross the information on education, gender and occupation. We find strong occupational differences between similarly educated men and women which suggests that they may compete for different types of jobs. Men and women might therefore be imperfect substitutes in production.

- Insert Table 3 about here -

The occupational differences between men and women may be an indicator of their imperfect substitutability if these two groups have different productive characteristics. If men and women of similar education have distinct characteristics, they should be in different occupations (as shown in Table 3) competing for different types of jobs. In addition, men and women of similar education may be considered as imperfect substitutes by employers due to gender discrimination. Such behaviors among employers could produce some imperfect substitutability between men and women (even if they are equally productive), leading to gender occupational differences as observed in Table 3.

\section{Elasticities of Substitution}

Elasticity of substitution between women and men. In order to estimate the elasticity of substitution between women and men, we examine how their relative supply changes line up with their relative wage changes. For the analysis, we divide our sample into 24 education and experience cells for each year of

our sample period. For each skill group, we compute the relative wage of women, $\left(w_{b j k t}^{\text {Female }} / w_{b j k t}^{\text {Male }}\right)$ and their relative labor supply, $\left(\right.$ Female $_{b j k t} /$ Male $\left._{b j k t}\right)$.

In Figure 2, we provide a preliminary look at the correlation between the relative supply of women and their relative wages. Figure 2 indicates a negative and significant relationship between relative wages and relative labor supplies across skill groups. The unconditional correlation between the relative wages and the relative supplies is about 0.07 which suggests an elasticity of substitution $\sigma_{F}$ of about 14 . This finding provides a first evidence of the imperfect substitutability between men and women.

- Insert Figure 2 about here -

In Figure 2, we implicitly assume a constant relative demand for women. This demand may however differ across skill groups and over time. It should therefore affect the relative wage of women and their relative labor supply. We thus need to estimate the causal impact of the relative supply of women on their relative wages. The estimation will take into account the systematic changes of female workers' relative productivity across skill groups and over time as well as the potential endogeneity of the relative supplies. In Equation (10), we consider the log of the relative wage of women in a particular skill group with the specification, 


$$
\log \left(\frac{w_{b j k t}^{\text {Female }}}{w_{b j k t}^{\text {Male }}}\right)=\log \left(\frac{\theta_{S_{F} b j k t}}{\theta_{S_{M} b j k t}}\right)-\frac{1}{\sigma_{F}} \cdot \log \left(\frac{\text { Female }_{b j k t}}{\text { Male }_{b j k t}}\right)
$$

where $w_{b j k t}^{F e m a l e}$ and $w_{b j k t}^{M a l e}$ are the wages of women and men workers in cell $(b j, k, t)$, respectively. In order to compute the dependent variable, we follow the standard approach and use the mean of log wages (Katz and Murphy, 1992; Borjas, 2003; Borjas, Grogger, and Hanson, 2012). The explanatory variable is the log relative number of female workers in employment. The term $\log \left(\theta_{S_{F} b j k t} / \theta_{S_{M} b j k t}\right)$ captures the relative productivity of women. In order to estimate the elasticity of substitution between men and women (denoted $\sigma_{F}$ ), we assume that the relative productivity term can be captured by a vector of fixed effects $\delta_{b j k t}$ and a group-specific error term $\xi_{b j k t}$ uncorrelated with the log relative supply of women. ${ }^{26}$

As the relative labor supplies are likely to be endogenous, we implement a set of instrumental variables (IV) regressions. For instance, a women-biased productivity shock in a specific cell could increase the cell-specific relative labor demand and relative wage of women, attracting relatively more women in those cells. Thus, the OLS estimates have to be interpreted as lower bounds of the true value of the elasticity of substitution. Our instrument is the relative number of single women within skill groups, $\left(\text { single }_{F} / \text { single }_{M}\right)_{b j k t}$. This instrument is related to the relative labor force market participation of women. As suggested by the literature on the female labor market participation, the marital status should affect the reservation wages and not the market wages of women (Cain and Dooley 1976; Blackaby, Leslie, Murphy, and O'Leary 2002; Mulligan and Rubinstein 2008). ${ }^{27}$ By affecting reservation wages, the marital status (being single or not) should thus be an important predictor of employment. ${ }^{28}$ As a result, a change in the relative number of single women should affect the relative number of women workers. This is supported by the lower-part of Table 4: our first stage estimated coefficients imply that our instrument is positively correlated with the relative number of female workers. ${ }^{29}$ This positive correlation indicates that single individuals are more likely to participate in the labor market. This result is consistent with the findings of Mulligan and Rubinstein (2008). The upper-part of Table 4 reports the OLS and the IV estimated coefficients of $-1 / \sigma_{F}$ using two alternative definitions of relative wages and two different

\footnotetext{
${ }^{26}$ Because the dependent variable is the ratio of female over male log wages, factors that affect symmetrically female and male labor demand are removed from the equation. Thus, "any biased technological change affecting the productivity of more educated (experienced) workers relative to less educated (experienced) workers would be washed out in the ratios" (Ottaviano and Peri (2012), p. 170).

${ }^{27}$ The labor force participation decision is generally based on a comparison of the market wage with the reservation wage. Individuals participate in the labor market when their offered wage exceeds their reservation wage (Killingsworth and Heckman, 1986; Heckman, 1993).

${ }^{28}$ This is shown empirically by Blackaby, Leslie, Murphy, and O'Leary (2002) for the United Kingdom.

${ }^{29}$ In addition, the F-test of exclusion is above 20. This is larger than the lower bound of 10 suggested by the literature on weak instruments.
} 
samples. We weight the observations by the inverse variance of the ratio of the log wages for each education-experience-time cell (Borjas, Grogger, and Hanson 2012; Brücker, Hauptmann, Jahn, and Upward 2014). We cluster the standard errors at the education-experience level to allow error correlation within skill group.

In all specifications, the coefficients are negative. It is significant in the full-time and part time sample (column 1) suggesting an imperfect substitution between men and women - a coefficient equal to -0.08 implies a substitution elasticity of 12.5 . The estimated coefficients of the IV regressions are negative and highly significant. Consistent with an upward bias in the OLS estimates, we find an even lower degree of substitutability between men and women in the IV regressions. The estimated coefficients range from 0.14 to 0.21 which correspond to elasticity of substitution of about 4.8 to 7.1 .

- Insert Table 4 about here -

Elasticity of substitution between natives and immigrants. We structurally derive an equation that allow us to estimate the degree of substitutability between immigrants and natives:

$$
\log \left(\frac{w_{S b j k t}^{M}}{w_{S b j k t}^{N}}\right)=\log \left(\frac{\theta_{S b j k t}^{M}}{\theta_{S b j k t}^{N}}\right)-\frac{1}{\sigma_{I}} \cdot \log \left(\frac{M_{S b j k t}}{N_{S b j k t}}\right)
$$

As compared to Equation (10), this equation has four main dimensions: education, experience, time and gender. The dependent variable is the relative log mean wage of immigrants in a particular skill-gender group at time $t$. On the right-hand side, the first and second terms capture the relative productivity of immigrants and the relative number of immigrants, respectively. The relative productivity of immigrants can be captured by a set of fixed effects. The identification assumption on the relative productivity term is one important debated point (Borjas, Grogger, and Hanson, 2012; Ottaviano and Peri, 2012). As for the estimation of $\sigma_{F}$, we use a saturated model by including all pair-wise interactions between the skill (i.e., education and experience), time and gender dummies. Each regression uses the inverse variance of of the ratio of the log wages as analytical weights. Standard errors are heteroscedasticity-robust and clustered around skill-gender groups.

- Insert Table 5 about here -

In Table 5, we report the estimated values of $-1 / \sigma_{I}$. As for Table 4 , we present the estimated coefficients of $-1 / \sigma_{I}$ using two alternative definitions of relative wages and two different samples. ${ }^{30}$ The

\footnotetext{
${ }^{30}$ Notice that the number of observations is 504 as we take into account the gender dimension in our estimation. In Equation (11), we identify $-1 / \sigma_{I}$ from changes that occur within gender-skill cells over time.
} 
estimates are from OLS and IV regressions although the literature rarely accounts for the endogeneity of the log relative number of immigrants. Our instrument is similar to the one used to compute the elasticity of substitution between men and women. We compute the relative number of single immigrants in a particular gender-skill group at time $t$. The first stage estimates (lower-part of Table 5) indicate that our instrument is positively correlated with the relative number of immigrant workers. This positive relationship is also consistent with the first stage results reported in Table 4. In a specific cell, the relative number of single individuals is positively correlated with their relative employment.

The OLS and IV estimates suggest that natives and immigrants of similar education and experience tend to be perfect substitutes in production. ${ }^{31}$ This finding is in line with Edo and Toubal (2015) for France and Aydemir and Borjas (2007) for Canada and the United States. In order to simulate the impact of immigrant on wages, we assume $\sigma_{I}$ to be infinity. However, given the mixed results regarding the degree of substitution between natives and immigrants reached in the literature we also assume imperfect substitution between immigrants and natives.

Elasticities of substitution between Education and Experience Groups. In order to simulate the wage effects of immigration for France, we also need to define the elasticity of substitution between the education groups. We rely on Edo and Toubal (2015) who already estimated these parameters for France over the 1990-2010 period. We thus assume the elasticity of substitution between the two broad education groups $\sigma_{H L}=4$ and between the medium and low educated groups $\sigma_{L}=10$. We will test the robustness of our simulations by using an alternative set of parameters from Ottaviano and Peri (2012): $\sigma_{H L}=2$ and $\sigma_{L}=20$.

For the elasticity of substitution between experience groups, we assume that $\sigma_{X}=7$. Our chosen value for $\sigma_{X}$ is in line with Card and Lemieux (2001) who find an elasticity between 5 and 10, Ottaviano and Peri (2012) who find an elasticity around 6.25, Manacorda, Manning, and Wadsworth (2012) who find $\sigma_{X}$ to be around 10 for the United Kingdom, and Edo and Toubal (2015) who find $\sigma_{X}=7.5$ for France.

\section{Empirical Results}

We first provide an econometric analysis of the effect of immigration within group of workers with similar education and experience. We estimate the impact of the relative labor supply of female immigrants within skill group on the relative wages of female native workers. We then take into account the impact

\footnotetext{
${ }^{31}$ While the two first IV coefficients are insignificant, the third one has the wrong sign.
} 
on native workers that are not competing in the same experience and education group by using a structural approach.

The within skill group estimations. The fact that within skill groups (i) men and women tend to be imperfect substitutes whereas (ii) immigrants and natives tend to be perfect substitutes has one important implication. An increase in the relative number of female immigrants within a skill group should affect negatively the relative wages of native women, widening the gender wage gap among native workers within that group. From Equation (10), we derive the following reduced form relative wage equation: ${ }^{32}$

$$
\log \left(\frac{w_{b j k t}^{\text {Female }}}{w_{b j k t}^{\text {Male }}}\right)^{N}=\beta \cdot\left[\left(\frac{M_{b j k t}}{N_{b j k t}}\right)_{b j k t}^{\text {Female }} /\left(\frac{M_{b j k t}}{N_{b j k t}}\right)_{b j k t}^{\text {Male }}\right]+\delta_{b j k}+\delta_{k t}+\delta_{b j t}+\eta_{b j k t}
$$

The immigrant/native ratio captures the relative size of the supply shock induced by immigrant women as compared to immigrant men. The numerator of this ratio measures the female immigrant supply shock experienced by a particular skill group. The denominator measures the male immigrant supply shock for the skill group.

When estimating Equation (12), we have to control for the fact that the native gender wage gap may differ across education and experience groups over time by including all possible fixed effects. $\delta_{b j k}$ is a vector of fixed effects including education fixed effects $\left(\delta_{b j}\right)$, experience fixed effects $\left(\delta_{k}\right)$ and their interaction $\left(\delta_{b j} \times \delta_{k}\right)$. This vector controls for all factors that are cell specific and invariant over time. The inclusions of $\delta_{k t}$ and $\delta_{b j t}$ control for the possibility that the gender wage gap may vary due to time-specific shocks, as well as for the fact that the impact of education and experience on relative wages may differ over time.

Our identifying strategy implies that $\beta$ is identified using time-variation within education-experience

\footnotetext{
${ }^{32}$ By assuming a pre-immigration period and using Equation (10), the change of the relative wage of female natives resulting from an exogenous inflow of male and female immigrants is:

$$
\begin{aligned}
& \triangle \log \left(w_{b j k t}^{\text {Female }} / w_{b j k t}^{\text {Male }}\right)^{N}=\Delta \log \left(\theta_{S_{F} b j k t} / \theta_{S_{M} b j k t}\right)^{N}+\xi \cdot \log \left[\frac{\left(\frac{\text { Female }_{b j k t}}{\text { Male }_{b j k t}}\right)^{N}\left(1+n_{b j k}\right)+\left(\frac{\text { Female }_{b j k t}}{\text { Male }_{b j k t}}\right)^{M}}{\left(\text { Female }_{b j k t} / \text { Male }_{b j k t}\right)^{N}}\right] \\
& \simeq \triangle \log \left(\theta_{S_{F} b j k t} / \theta_{S_{M} b j k t}\right)^{N}+\xi \cdot\left[n_{b j k}+m_{b j k t}\right] . \\
& m_{b j k t}=\left(\frac{\text { Female }_{b j k t}}{\text { Male }_{b j k t}}\right)^{M} /\left(\frac{\text { Female }_{b j k t}}{\text { Male }_{b j k t}}\right)^{N}=\left(\frac{M_{b j k t}}{N_{b j k t}}\right)_{b j k t}^{\text {Female }} /\left(\frac{M_{b j k t}}{N_{b j k t}}\right)_{b j k t}^{\text {Male }} \text { is the immigrant/native ratio which is cell }
\end{aligned}
$$
specific and varies over time. $n_{b j k}$ is the percent change in the relative number of native female workers. It is assumed to be cell specific and invariant over time.
} 
cells. As noted in Ottaviano and Peri (2012), since we use relative wages and relative labor supplies at the skill-cell level, any (unobserved) specific shock at the skill-cell level that affects the labor market conditions of workers homogeneously should not bias our estimates (see Footnote 26).

The regression results are reported in Table 6 . We weight each regression to account for differential precision in the measure of relative wages across cells. As a weight, we follow Borjas, Grogger, and Hanson (2012) and we use the inverse of the sampling variance of the dependent variable. We also cluster the standard errors by education-experience groups.

We investigate whether our results are robust to alternative definition of the relative supply shock induced by female immigrant workers. We use:

- (Female Immigrants/Male Immigrants $)_{b j k t}$. This ratio is similar to our baseline measure when assuming that the number of female and male native workers is identical.

- $\log (\text { Female Immigrants/Male Immigrants })_{b j k t}$. We take the log of the relative number of immigrant workers to have an equation that is very close to Equation (10). In addition, taking the log of the female immigrant ratio can facilitate the interpretation of the estimated coefficients.

- $\log (\text { Female Immigrants/All Immigrants })_{b j k t}$. In this latter measure of the supply shock induced by female/male immigrants, the denominator is the total number of immigrant workers (men and women).

In Panel A, we use our baseline measure to capture the immigration-induced increase in the supply of workers. Panels $B, C$ and $D$ respectively use our second, third and fourth measures to capture the relative labor supply shock induced by female immigrants. We use an OLS and an IV set of regressions. In order to implement the IV regressions, we use the ratio between the number of single immigrant women and the number of single immigrant men. The first stage estimates of the IV regression indicate a positive and significant correlation between the instrument and the relative number of female immigrant workers. These results are consistent with our previous findings: single individuals are more likely to be in employment - one reason is that single individuals have lower reservation wages. Moreover, the F-statistics indicate that our IV estimates do not suffer from a weak instrument problem.

- Insert Table 6 about here -

The estimated coefficients using OLS are always negative and significant. This finding is in line with the imperfect substitution elasticity between women and men. Instrumenting for the immigrant share produces negative effects that are stronger. The negative OLS estimates of $\beta$ have to be interpreted as a lower bound of the true immigration impact. 
In Panel A, the estimated coefficients are smaller than the ones in Panel B partly because of a smaller female immigration-induced supply shock. The numerator of the variable in Panel A reduces the size of the supply shock induced by female immigrants as the labor force participation rate of native women has raised drastically since 1990. In Panel B, the supply shock induced by female immigrants is larger since the increase in the number of immigrants workers in France has been mainly due to women.

In Panels $C$ and $D$, we can interpret the estimated coefficients as elasticities. In Panel C, we find that an increase of $10 \%$ in the relative number of female immigrants reduces the relative hourly wage of competing female natives by $4 \%$. The estimated coefficient from Panel D implies that a $10 \%$ increase in the female immigrants population in a particular skill group reduces the native wage gap by $6 \% .33$

The results reported in Table 6 point to a negative effect of the relative increase in the supply of female immigrants on the relative wage of female native workers within the same education-experience group.

Results from the structural approach. Table 7 reports the simulated effects of immigration on the mean wage of native workers in the long-run along with the distributional effects of immigration by gender and education. We use alternative parameter values to implement our simulations. They are reported in the upper-part of Table 7.

- Insert Table 7 about here -

The left-hand side of the table assumes $\sigma_{F}=12.5$ (columns 1 to 4 ). Columns 1 and 2 indicate that immigration has no detrimental effect on the average wage of native workers in the long-run. In columns 3 and 4, we assume natives and immigrants to be imperfect substitutes, and we find a small positive impact on native wages in the long-run. Columns 1 to 4 also indicate that immigration has decreased the relative average wage of female native workers (relative to male natives) over the past two decades. Columns 1 and 2 even show that immigration has decreased the wages of female natives and increased those of male natives. The asymmetric wage effect of immigration by gender is driven by the assumption of imperfect substitutability between men and women, and it is robust to the assumption made about the degree of substitutability between natives and immigrants.

The right-hand side of the table assumes $\sigma_{H L}=4$ and $\sigma_{L}=10$, and it examines the wage effect of immigration under the case where the degree of substitutability between men and women is $\sigma_{F}=5$ and the extreme case where $\sigma_{F} \rightarrow \infty$. When we assume $\sigma_{F}=5$, immigration induces important wage losses among women and wage gains among men, implying a stronger negative effect on the relative wage

\footnotetext{
${ }^{33}$ Panel D indicates a stronger negative impact since the size of the denominator is larger than in Panel C. In fact, the supply shock generated by a $10 \%$ increase in the relative number of female immigrants is larger in Panel D than in Panel C.
} 
of female natives. As expected, column 6 (where men and women are perfect substitutes) shows that immigration has a symmetric effect on the wages of men and women.

These different average effects (across columns) can be decomposed by education groups. In line with the fact that the share of high educated immigrants substantially increased over our period (as shown in Table 1), the negative wage effects of immigration are mainly driven by the wage losses experienced by the highly educated male and female native workers. More specifically, immigration has decreased their wages by between $-0.4 \%$ and $-1.0 \%{ }^{34}$ We also find that both low and medium educated natives have experienced a slight improvement in their wage levels. Similar results are found in Edo and Toubal (2015). However, the imperfect substitutability between men and women induces lower wage losses among the high educated male natives compared to female natives; as well as higher wage gains among the medium and low educated native men.

Table 8 aims at comparing the mean effect of immigration on the gender wage gap under rigid labor market with the reference case of perfect labor markets. More specifically, this table reports the effects of immigration on the wages of female and male natives according to whether wages are assumed to be rigid (left-hand side) or perfectly flexible (right-hand side). We set $\sigma_{H L}=4$ and $\sigma_{L}=10$ (Edo and Toubal, 2015). For each scenario, we assume different degree of substitutability between men and women, as well as between immigrants and natives. For each simulation, we compute the difference between the wage changes of male and female native workers. A positive number implies that immigration has increased the gender wage gap.

- Insert Table 8 about here -

First, our results indicate that the negative effect of immigration on the gender wage gap is greater when $\sigma_{F}$ is low and $\sigma_{I}$ is high. Second, the impact of immigration on the relative wage of female natives is lower in rigid labor markets than in flexible labor markets. This finding points out the important role played by labor market rigidities in dampening the impact of immigration on the gender wage dispersion.

It is important to note that the two types of simulations (according to whether we assume rigid or flexible labor market) can be interpreted as giving numerical bounds for the wage effects of immigration. Actually, it might be that the displacement effects due to immigration (inducing indirect wage effects) are not identical across all labor market cells, but rather concentrated in some skill-cells. ${ }^{35} \mathrm{~A}$ reason for such asymmetric displacement effects may lie in the fact that some skill-cells are less affected by wage

\footnotetext{
${ }^{34}$ The asymmetric wage impact of immigration across education groups is reinforced when we assume $\sigma_{H L}=2-i . e$. a very low degree of substitution between the two broad education groups. In fact, when we assume $\sigma_{H L}=2$, the wage effect induced by (a high educated) immigration is more concentrated among the highly educated natives, rather than diffused among all native workers.

${ }^{35}$ In this regard, Edo (2015) finds that the negative effects of immigration on the employment of competing native workers are mostly concentrated within the medium and low educated segments of the French labor market.
} 
rigidities. As a result, the effect of immigration on the average wages of natives in France should be somewhere between a scenario where all wages are rigid and a scenario where wages are perfectly flexible.

\section{Conclusion}

France has experienced in the last two decades an important increase in the supply of female immigrant workers. We examine the impact of the feminization of the migration population on the wages of native female and male workers.

The impact of the feminization of the labor force on the gender wage gap depends on whether men and women are "poor" or "good" substitutes (Topel, 1997). If men and women are "poor" substitutes, the rising labor supply of immigrant women should therefore affect the gender wage gap. The degree of substitutability between men and women is therefore crucial for our study. We therefore develop a structural model to estimate the elasticity of substitution between men and women of similar education and experience. We find a significant degree of imperfect substitutability between men and women workers. The literature in economics, sociology and psychology points to numerous drivers of this imperfect substitution (Maltz and Borker, 1982; Charles and Grusky, 2005; Croson and Gneezy, 2009).

We find that an immigration-induced increase in female labor supply in a skill-cell reduces the relative wage of female natives in that cell. This finding is consistent with our result of imperfect substitutability. Since men and women are "poor" substitutes, the rise in the relative supply of women due to immigration has reduced the relative wage of native women, thereby contributing to a widening gender wage gap.

Our structural model quantifies the distributional effects of female immigration by accounting for the cross-cell effects induced by immigration. The long-run simulations reveal that the increasing feminization of the immigrant labor force has been detrimental for the relative wage of female natives. In particular, our preferred specification indicates that immigration has lowered the wage of female natives by $0.28 \%$ and increased the wage of male natives by about $0.16 \%$ over our period of interest (1990-2010).

Our results suggest that the gender composition of immigrants matters in determining their impact on the wage gap between male and female natives. 


\section{References}

Acemoglu, D., D. Autor, And D. Lyle (2004): "Women, war, and wages: The effect of female labor supply on the wage structure at midcentury," Journal of Political Economy, 112(3), 497-551.

Altonji, J., and R. Blank (1999): "Race and gender in the labor market," Handbook of Labor Economics, 3, 3143-3259.

Amuedo-Dorantes, C., And S. De La Rica (2011): "Complements or substitutes? Task specialization by gender and nativity in Spain," Labour Economics, 18(5), 697-707.

Anker, R., ET AL. (1998): Gender and jobs: Sex segregation of occupations in the world. Cambridge Univ Press.

Autor, D. H., L. F. Katz, and M. S. KeARney (2008): "Trends in US wage inequality: Revising the revisionists," The Review of Economics and Statistics, 90(2), 300-323.

Aydemir, A., And G. J. BorJas (2007): "Cross-country variation in the impact of international migration: Canada, Mexico, and the United States," Journal of the European Economic Association, 5(4), 663-708.

AydemiR, A., And G. J. BorJas (2011): "Attenuation Bias in Measuring the Wage Impact of Immigration," Journal of Labor Economics, 29(1), 69-112.

Babeckỳ, J., P. Du Caju, T. Kosma, M. Lawless, J. Messina, and T. Rõõm (2010): “Downward Nominal and Real Wage Rigidity: Survey Evidence from European Firms*," The Scandinavian Journal of Economics, 112(4), 884-910.

Barone, G., And S. Mocetti (2011): "With a little help from abroad: the effect of low-skilled immigration on the female labour supply," Labour Economics, 18(5), 664-675.

Beauchemin, C., C. Borrel, and C. Régnard (2013): "Immigrants in France: a female majority.," Population \& Sociétés, (502).

Blackaby, D. H., D. G. Leslie, P. D. Murphy, and N. C. O'Leary (2002): "White/ethnic minority earnings and employment differentials in Britain: evidence from the LFS," Oxford Economic Papers, 54(2), 270-297.

Blau, F., and L. Kahn (2000): "Gender Differences in Pay," Journal of Economic Perspectives, 14(4), 75-99. 
Blau, F. D., M. A. Ferber, and A. E. Winkler (2002): The economics of women, men, and work, vol. 4. Prentice Hall Upper Saddle River, NJ.

BorJAs, G. J. (2003): "The labor demand curve is downward sloping: reexamining the impact of immigration on the labor market," The quarterly journal of economics, 118(4), 1335-1374.

BorJAs, G. J. (2006): "Native internal migration and the labor market impact of immigration," Journal of Human Resources, 41(2), 221-258.

(2014): Immigration Economics. Harvard University Press.

Borjas, G. J., J. Grogger, and G. H. Hanson (2008): "Imperfect substitution between immigrants and natives: a reappraisal," Discussion paper, National Bureau of Economic Research.

(2011): "Substitution Between Immigrants, Natives, and Skill Groups," Discussion paper, National Bureau of Economic Research.

- (2012): "Comment: On Estimating Elasticities Of Substition," Journal of the European Economic Association, 10(1), 198-210.

BorJas, G. J., And L. F. Katz (2007): "The evolution of the Mexican-born workforce in the United States," in Mexican immigration to the United States, pp. 13-56. University of Chicago Press.

Brücker, H., A. Hauptmann, E. J. Jahn, and R. Upward (2014): "Migration and imperfect labor markets: Theory and cross-country evidence from Denmark, Germany and the UK," European Economic Review, 66, 205-225.

BrüCKer, H., And E. J. JAhn (2011): "Migration and Wage-setting: Reassessing the Labor Market Effects of Migration," The Scandinavian Journal of Economics, 113(2), 286-317.

Cain, G. G., And M. D. Dooley (1976): "Estimation of a model of labor supply, fertility, and wages of married women," Journal of Political Economy, pp. S179-S199.

CARD, D. (2009): "Immigration and Inequality," The American Economic Review, pp. 1-21.

(2012): "Comment: The elusive search for negative wage impacts of immigration," Journal of the European Economic Association, 10(1), 211-215.

Card, D., F. Kramarz, and T. Lemieux (1999): "Changes in the Relative Structure of Wages and Employment: A Comparison of the United States, Canada, and France," The Canadian Journal of Economics, 32(4), 843-877. 
Card, D., and T. Lemieux (2001): "Can Falling Supply Explain the Rising Return to College for Younger Men? A Cohort-Based Analysis," The Quarterly Journal of Economics, 116(2), 705-746.

Charles, M., And D. B. Grusky (2005): Occupational ghettos: The worldwide segregation of women and men. Stanford University Press.

Cohen, D., A. Lefranc, and G. Saint-Paul (1997): "French unemployment: a transatlantic perspective," Economic Policy, 12(25), 265-292.

Collado, M. D., I. Iturbe-Ormaetxe, and G. Valera (2004): "Quantifying the impact of immigration on the Spanish welfare state," International Tax and Public Finance, 11(3), 335-353.

Cortes, P. (2008): "The effect of low-skilled immigration on US prices: evidence from CPI data," Journal of political Economy, 116(3), 381-422.

Cortes, P., And J. Tessada (2011): "Low-skilled immigration and the labor supply of highly skilled women," American Economic Journal: Applied Economics, 3(3), 88-123.

Croson, R., And U. Gneezy (2009): "Gender differences in preferences," Journal of Economic literature, pp. 448-474.

D'Amuri, F., G. I. Ottaviano, and G. Peri (2010): "The labor market impact of immigration in Western Germany in the 1990s," European Economic Review, 54(4), 550-570.

Division, U. N. P. (2013): International Migration Report 2013.

Docquier, F., B. L. Lowell, and A. Marfouk (2009): “A gendered assessment of highly skilled emigration," Population and Development Review, 35(2), 297-321.

Docquier, F., A. Marfouk, S. Salomone, and K. Sekkat (2012): "Are skilled women more migratory than skilled men?," World Development, 40(2), 251-265.

Docquier, F., Ç. Ozden, and G. Peri (2013): "The Labour Market Effects of Immigration and Emigration in OECD Countries," The Economic Journal.

Dustmann, C., T. Frattini, and I. Preston (2007): A study of migrant workers and the national minimum wage and enforcement issues that arise. Low Pay Commission.

Dustmann, C., T. Frattini, and I. P. Preston (2013): "The effect of immigration along the distribution of wages," The Review of Economic Studies, 80(1), 145-173. 
ECCLES, J. S. (1994): "Understanding women's educational and occupational choices," Psychology of women quarterly, 18(4), 585-609.

EDO, A. (2015): "The Impact of Immigration on Native Wages and Employment," The B.E. Journal of Economic Analysis \& Policy (forthcoming).

Edo, A., And F. Toubal (2015): "Selective Immigration Policies and Wages Inequality," Review of International Economics, 23(1), 160-187.

Elsner, B. (2013): "Emigration and wages: The EU enlargement experiment," Journal of International Economics, 91(1), 154-163.

Farré, L., L. GonzÁlez, and F. Ortega (2011): "Immigration, family responsibilities and the labor supply of skilled native women," The BE Journal of Economic Analysis \& Policy, 11(1).

Felbermayr, G., W. Geis, and W. Kohler (2010): "Restrictive immigration policy in Germany: pains and gains foregone?," Review of World Economics, 146(1), 1-21.

Forlani, E., E. Lodigiani, and C. Mendolicchio (2015): "Impact of Low-Skilled Immigration on Female Labour Supply," The Scandinavian Journal of Economics, 117(2), 452-492.

Gerfin, M., And B. Kaiser (2010): "The Effects of Immigration on Wages: An Application of the Structural Skill-Cell Approach," Swiss Journal of Economics and Statistics, 146(4), 709-739.

Glitz, A. (2012): "The labor market impact of immigration: A quasi-experiment exploiting immigrant location rules in Germany," Journal of Labor Economics, 30(1), 175-213.

Goldin, C. (2014): "A grand gender convergence: Its last chapter," The American Economic Review, 104(4), 1091-1119.

Goldin, C. D., And L. F. Katz (2009): The race between education and technology. Harvard University Press.

Heckman, J. J. (1993): "What has been learned about labor supply in the past twenty years?," The American Economic Review, 83(2), 116-121.

Juhn, C., And D. I. Kim (1999): "The effects of rising female labor supply on male wages," Journal of Labor Economics, 17(1), 23-48.

JURAJDA, Š. (2003): "Gender wage gap and segregation in enterprises and the public sector in late transition countries," Journal of comparative Economics, 31(2), 199-222. 
Katz, L., And K. Murphy (1992): "Changes in relative wages, 1963-1987: supply and demand factors," The Quarterly Journal of Economics, 107(1), 35-78.

Killingsworth, M. R., And J. J. Heckman (1986): "Female labor supply: A survey," Handbook of labor economics, 1, 103-204.

Maltz, D. N., And R. A. Borker (1982): "A cultural approach to male-female miscommunication," New York: Cambridge University Press, pp. 168-185.

Manacorda, M., A. Manning, and J. Wadsworth (2012): "The Impact of Immigration on the Structure of Wages: Theory and Evidence from Britain," Journal of the European Economic Association.

Marcelli, E. A., And W. A. Cornelius (2001): "The changing profile of Mexican migrants to the United States: New evidence from California and Mexico," Latin American Research Review, pp. 105-131.

Mincer, J. A. (1974): Schooling, Experience and Earnings. New York: Columbia University Press.

Mulligan, C. B., And Y. Rubinstein (2008): "Selection, Investment, and Women's Relative Wages over Time," The Quarterly Journal of Economics, 123(3), pp. 1061-1110.

OmelaniuK, I. (2005): "Gender, poverty reduction and migration," World Bank, pp. 1-18.

Ottaviano, G. I., And G. Peri (2012): "Rethinking the effects of immigration on wages," Journal of the European Economic Association, 10, 152-197.

Sikora, J., And A. Pokropek (2011): "Gendered career expectations of students: Perspectives from PISA 2006," Discussion paper, OECD Publishing.

TOPEL, R. H. (1997): "Factor proportions and relative wages: the supply-side determinants of wage inequality," The Journal of Economic Perspectives, pp. 55-74.

Zlotnik, H. (1995): "The South-to-North migration of women," International Migration Review, pp. 229-254. 


\section{Figures}

Figure 1: The Gender Distribution of Immigrants over Time

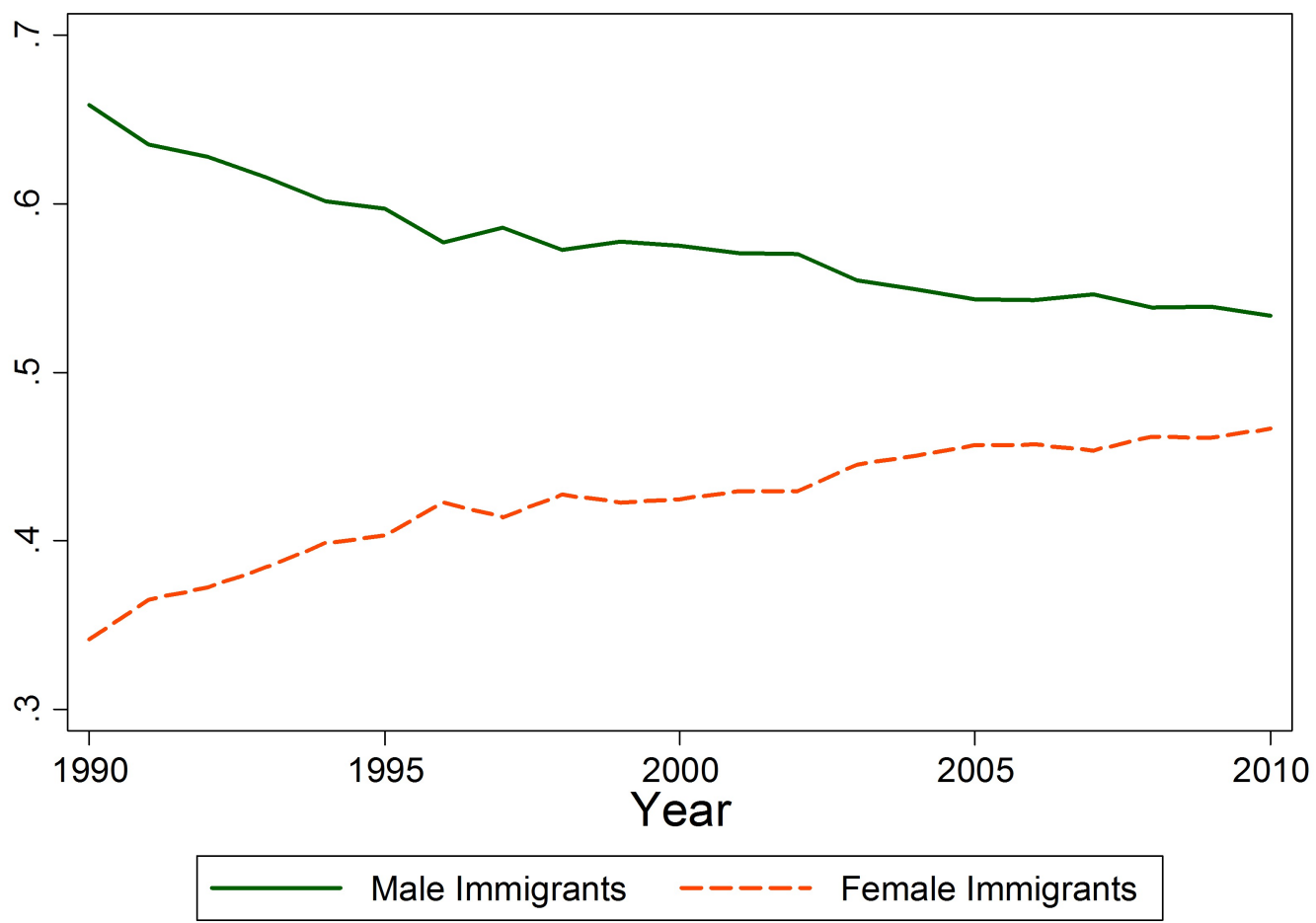

Notes. The Figure reports the shares of male and female immigrants in the immigrant labor force between 1990 and 2010 . The population used to compute these shares includes all immigrants participating in the labor force aged from 16 to 64 , not enrolled at school and having between 1 and 40 years of labor market experience. Self-employed people, workers in military occupations and the clergy are excluded from the sample. 
Figure 2: Correlation between Relative Wage of Women and their Relative Labor Supply

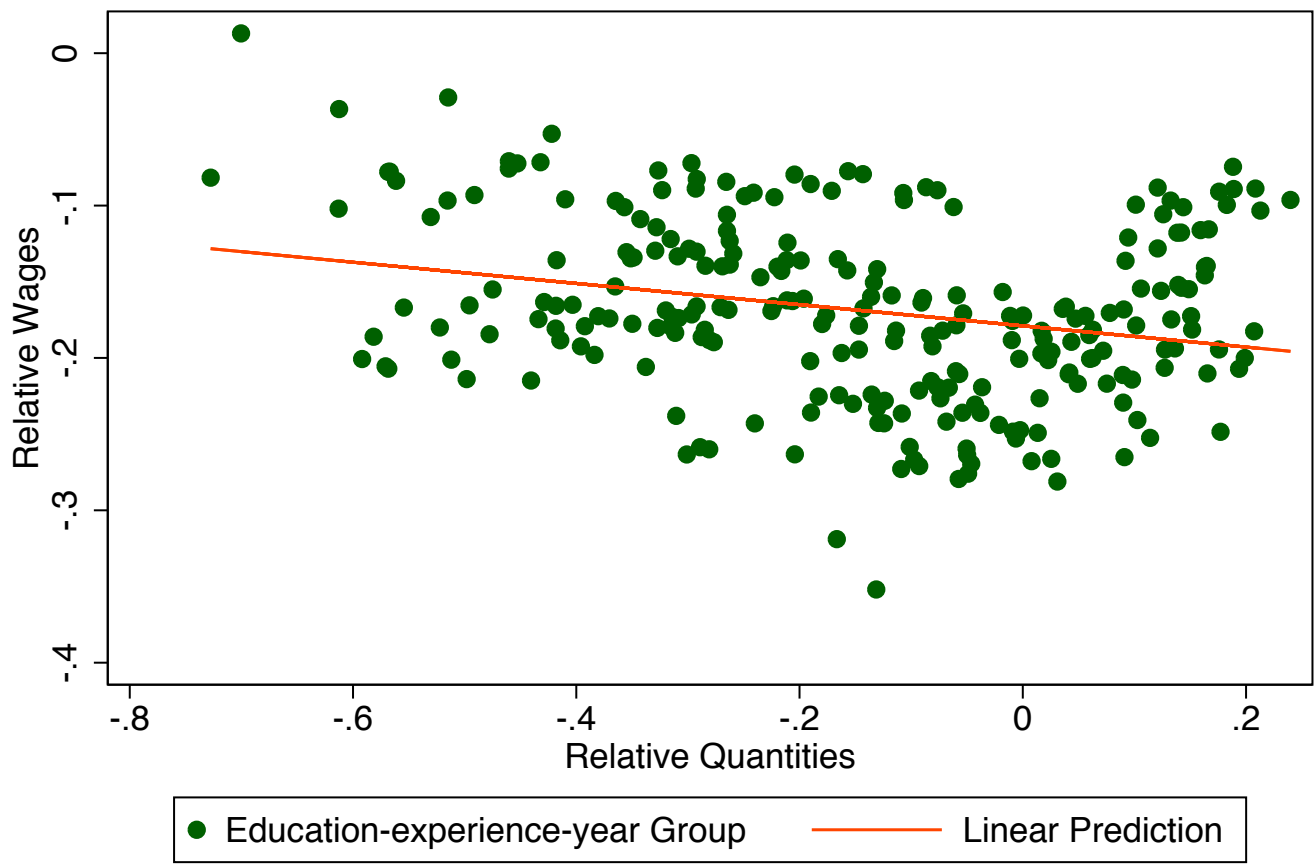

Notes. The Figure provides the basic correlation between the relative wage of women and their relative labor supply by educationexperience group in all years considered. The graphs give the log female-male hourly wage, $\log \left(w_{b j k t}^{F} / w_{b j k t}^{M}\right)$, on the vertical axis and the log female-male labor supply, $\log \left(\right.$ Female $_{b j k t} /$ Male $\left._{b j k t}\right)$, on the horizontal axis. Each observation corresponds to an education-experience group in one of the considered year. 


\section{Tables}

Table 1: Educational Distribution by Gender and Origin in 1990 and 2010

\begin{tabular}{|c|c|c|c|c|c|c|c|c|}
\hline & \multicolumn{4}{|c|}{ Males } & \multicolumn{4}{|c|}{ Females } \\
\hline & \multicolumn{2}{|c|}{ Natives } & \multicolumn{2}{|c|}{ Immigrants } & \multicolumn{2}{|c|}{ Natives } & \multicolumn{2}{|c|}{ Immigrants } \\
\hline & 1990 & 2010 & 1990 & 2010 & 1990 & 2010 & 1990 & 2010 \\
\hline High Education & $15.7 \%$ & $30.6 \%$ & $9.6 \%$ & $24.6 \%$ & $18.8 \%$ & $37.4 \%$ & $9.2 \%$ & $29.4 \%$ \\
\hline Medium Education & $46.0 \%$ & $47.6 \%$ & $21.8 \%$ & $34.6 \%$ & $42.0 \%$ & $43.3 \%$ & $20.2 \%$ & $32.7 \%$ \\
\hline Low Education & $38.2 \%$ & $21.8 \%$ & $68.7 \%$ & $40.8 \%$ & $39.2 \%$ & $19.4 \%$ & $70.7 \%$ & $37.9 \%$ \\
\hline Total & $100 \%$ & $100 \%$ & $100 \%$ & $100 \%$ & $100 \%$ & $100 \%$ & $100 \%$ & $100 \%$ \\
\hline
\end{tabular}


Table 2: Occupation by Gender and Origin (Average Share, 1990-2010)

\begin{tabular}{|c|c|c|c|c|}
\hline & \multicolumn{2}{|c|}{ Males } & \multicolumn{2}{|c|}{ Females } \\
\hline & Natives & Immigrants & Natives & Immigrants \\
\hline Professionals \& Managers & $17.7 \%$ & $11.9 \%$ & $10.4 \%$ & $8.7 \%$ \\
\hline Supervisors & $25.1 \%$ & $14.1 \%$ & $25.1 \%$ & $12.9 \%$ \\
\hline Administrative Workers & $14.7 \%$ & $13.2 \%$ & $52.7 \%$ & $55.3 \%$ \\
\hline Skilled-Manual Workers & $25.6 \%$ & $33.9 \%$ & $3.9 \%$ & $6.0 \%$ \\
\hline Unskilled-Manual Workers & $16.9 \%$ & $26.8 \%$ & $7.9 \%$ & $17.1 \%$ \\
\hline Total & $100 \%$ & $100 \%$ & $100 \%$ & $100 \%$ \\
\hline
\end{tabular}

Professionals and Managers: Manager of public sector; Professor and scientific profession; art, spectacles and information related professions; Administrative and commercial managers; Engineers and technical manager. Supervisors: School teachers, teachers and similar; Intermediate health professions and social work; Professionals in the public administration; Professionals in private companies; Technicians; Foremen, supervisors. Administrative Workers: Employees and agents of the public administration; Administrative employees; Commercial Workers Personal services. Skilled-Manual Workers: Skilled industrial workers; Skilled craft workers; Skilled handling, storage and transport. Unskilled-Manuals Workers: Drivers; Unskilled industrial workers; Unskilled craft workers; Laborers. 
Table 3: Occupational Distribution by Gender, Origin and Education (1990-2010)

\begin{tabular}{|c|c|c|c|c|}
\hline & \multicolumn{2}{|c|}{ Males } & \multicolumn{2}{|c|}{ Females } \\
\hline & Natives & Immigrants & Natives & Immigrants \\
\hline & \multicolumn{4}{|c|}{ A. High Education } \\
\hline Professionals \& Managers & $53.2 \%$ & $49.2 \%$ & $28.6 \%$ & $32.0 \%$ \\
\hline Supervisors & $35.5 \%$ & $25.6 \%$ & $50.0 \%$ & $33.7 \%$ \\
\hline Administrative Workers & $7.3 \%$ & $12.9 \%$ & $20.3 \%$ & $31.1 \%$ \\
\hline Skilled-Manual Workers & $2.4 \%$ & $6.4 \%$ & $0.6 \%$ & $1.2 \%$ \\
\hline Unskilled-Manual Workers & $1.6 \%$ & $5.8 \%$ & $0.5 \%$ & $1.9 \%$ \\
\hline \multirow[t]{2}{*}{ Total } & $100 \%$ & $100 \%$ & $100 \%$ & $100 \%$ \\
\hline & \multicolumn{4}{|c|}{ B. Medium Education } \\
\hline Professionals \& Managers & $8.1 \%$ & $5.6 \%$ & $3.9 \%$ & $4.3 \%$ \\
\hline Supervisors & $25.9 \%$ & $19.1 \%$ & $18.8 \%$ & $13.1 \%$ \\
\hline Administrative Workers & $16.1 \%$ & $15.2 \%$ & $66.7 \%$ & $64.9 \%$ \\
\hline Skilled-Manual Workers & $34.1 \%$ & $39.3 \%$ & $4.1 \%$ & $6.6 \%$ \\
\hline Unskilled-Manual Workers & $15.8 \%$ & $20.9 \%$ & $6.5 \%$ & $11.1 \%$ \\
\hline \multirow[t]{2}{*}{ Total } & $100 \%$ & $100 \%$ & $100 \%$ & $100 \%$ \\
\hline & \multicolumn{4}{|c|}{ C. Low Education } \\
\hline Professionals \& Managers & $4.9 \%$ & $1.5 \%$ & $1.7 \%$ & $0.7 \%$ \\
\hline Supervisors & $15.3 \%$ & $7.0 \%$ & $9.3 \%$ & $3.5 \%$ \\
\hline Administrative Workers & $18.4 \%$ & $12.3 \%$ & $64.2 \%$ & $60.7 \%$ \\
\hline Skilled-Manual Workers & $30.4 \%$ & $41.2 \%$ & $7.1 \%$ & $7.8 \%$ \\
\hline Unskilled-Manual Workers & $31.0 \%$ & $38.1 \%$ & $17.7 \%$ & $27.3 \%$ \\
\hline Total & $100 \%$ & $100 \%$ & $100 \%$ & $100 \%$ \\
\hline
\end{tabular}

Professionals and Managers: Manager of public sector; Professor and scientific profession; art, spectacles and information related professions; Administrative and commercial managers; Engineers and technical manager. Supervisors: School teachers, teachers and similar; Intermediate health professions and social work; Professionals in the public administration; Professionals in private companies; Technicians; Foremen, supervisors. Administrative Workers: Employees and agents of the public administration; Administrative employees; Commercial Workers Personal services. Skilled-Manual Workers: Skilled industrial workers; Skilled craft workers; Skilled handling, storage and transport. Unskilled-Manuals Workers: Drivers; Unskilled industrial workers; Unskilled craft workers; Laborers. 
Table 4: Estimates of $-1 / \sigma_{F}$, the Inverse Elasticity of Substitution between Men and Women

\begin{tabular}{|c|c|c|c|c|c|c|c|}
\hline & & \multicolumn{4}{|c|}{ Hourly Wage } & \multicolumn{2}{|c|}{ Monthly Wage } \\
\hline & & \multicolumn{2}{|c|}{ Full- and Part-time } & \multicolumn{2}{|c|}{ Full-time Only } & \multicolumn{2}{|c|}{ Full-time Only } \\
\hline & & OLS & IV & OLS & IV & OLS & IV \\
\hline$-1 / \hat{\sigma}_{F}$ & & $\begin{array}{c}-0.08 * * \\
(-2.26)\end{array}$ & $\begin{array}{c}-0.21 * * * \\
(-4.31)\end{array}$ & $\begin{array}{l}-0.07 * \\
(-2.03)\end{array}$ & $\begin{array}{c}-0.14 * * \\
(-2.40)\end{array}$ & $\begin{array}{c}-0.07 \\
(-1.73)\end{array}$ & $\begin{array}{c}-0.16 * * * \\
(-3.19)\end{array}$ \\
\hline \multirow[t]{3}{*}{ First Stage: } & Instrument & - & $0.21^{* * *}$ & - & $0.19 * *$ & - & $0.20 * *$ \\
\hline & T-statistic & - & $(4.88)$ & - & $(2.87)$ & - & $(2.72)$ \\
\hline & F-statistic & - & 23.83 & - & 8.22 & - & 7.37 \\
\hline Observations & & 252 & 252 & 252 & 252 & 252 & 252 \\
\hline
\end{tabular}

Key. $* * *, * *, *$ denote statistical significance from zero at the $1 \%, 5 \%, 10 \%$ significance level. T-statistics are indicated in parentheses below the point estimate.

Notes. The dependent variable is the relative log mean wage of women. The explanatory variable is the log relative number of female employment in each cell. We use two different samples: one including part-time workers, one focusing on full-time workers only. All regressions include education, experience, and time fixed effects, as well as interactions between education and experience fixed effects, education and time fixed effects, and experience and time fixed effects. The standard errors are adjusted for clustering at the education and experience level. 
Table 5: Estimates of $-1 / \sigma_{I}$, the Inverse Elasticity of Substitution between Natives and Immigrants

\begin{tabular}{|c|c|c|c|c|c|c|c|}
\hline & & \multicolumn{4}{|c|}{ Hourly Wage } & \multirow{2}{*}{\multicolumn{2}{|c|}{$\begin{array}{l}\text { Monthly Wage } \\
\text { Full-time Only }\end{array}$}} \\
\hline & & \multicolumn{2}{|c|}{ Full- and Part-time } & \multicolumn{2}{|c|}{ Full-time Only } & & \\
\hline & & OLS & IV & OLS & IV & OLS & IV \\
\hline \multirow[t]{2}{*}{$-1 / \hat{\sigma}_{I}$} & & 0.01 & -0.03 & 0.10 & 0.02 & 0.07 & $0.17 * * *$ \\
\hline & & $(0.10)$ & $(-0.29)$ & $(1.44)$ & $(0.19)$ & $(1.43)$ & $(2.65)$ \\
\hline \multirow[t]{3}{*}{ First Stage: } & Instrument & - & $5.04 * * *$ & - & $4.82 * * *$ & - & $5.40 * * *$ \\
\hline & T-statistic & - & $(4.21)$ & - & $(3.22)$ & - & $(3.15)$ \\
\hline & F-statistic & - & 17.69 & - & 10.36 & - & 9.93 \\
\hline Observations & & 504 & 504 & 504 & 504 & 504 & 504 \\
\hline
\end{tabular}

Key. $* * *, * *, *$ denote statistical significance from zero at the $1 \%, 5 \%, 10 \%$ significance level. T-statistics are indicated in parentheses below the point estimate.

Notes. The dependent variable is the relative log mean wage of immigrants. The explanatory variable is the log relative number of immigrant employment in each cell. We use two different samples: one including part-time workers, one focusing on full-time workers only. All regressions include a complete set of gender-skill fixed effects, skill-time fixed effects, and gender-time fixed effects. The standard errors are adjusted for clustering at the gender-skill level. 
Table 6: The Within-cell Effect of Immigrant Women on the Native Gender Wage Gap

\begin{tabular}{|c|c|c|c|c|c|}
\hline & & \multicolumn{2}{|c|}{ Hourly Wage } & \multicolumn{2}{|c|}{ Monthly Wage } \\
\hline & & OLS & IV & OLS & IV \\
\hline \multirow{2}{*}{\multicolumn{2}{|c|}{ A. Immigrant/Native Ratio }} & $-0.02 *$ & $-0.06 * * *$ & $-0.02 * * *$ & $-0.04 * * *$ \\
\hline & & $(-1.88)$ & $(-4.37)$ & $(-3.28)$ & $(-3.51)$ \\
\hline \multirow[t]{3}{*}{ First Stage: } & Instrument & - & $0.43^{* *}$ & - & $0.44 * *$ \\
\hline & T-statistic & - & $(2.93)$ & - & $(2.88)$ \\
\hline & F-statistic & - & 79.80 & - & 66.42 \\
\hline \multirow{2}{*}{\multicolumn{2}{|c|}{ B. Female Immigrant Ratio }} & $-0.03 * *$ & $-0.07 * * *$ & $-0.03 * *$ & $-0.05 * * *$ \\
\hline & & $(-2.49)$ & $(-4.46)$ & $(-3.03)$ & $(-3.58)$ \\
\hline \multirow[t]{3}{*}{ First Stage: } & Instrument & - & $0.40 * * *$ & - & $0.41^{* * *}$ \\
\hline & T-statistic & - & $(3.40)$ & - & $(3.29)$ \\
\hline & F-statistic & - & 66.41 & - & 54.11 \\
\hline \multirow{2}{*}{\multicolumn{2}{|c|}{ C. Log of Immigrant Ratio }} & $-0.01^{*}$ & $-0.04 * * *$ & $-0.02 * * *$ & $-0.03 * * *$ \\
\hline & & $(-2.06)$ & $(-5.17)$ & $(-3.22)$ & $(-4.05)$ \\
\hline \multirow[t]{3}{*}{ First Stage: } & Instrument & - & $0.71^{* *}$ & - & $0.72 * *$ \\
\hline & T-statistic & - & $(2.97)$ & - & $(2.88)$ \\
\hline & F-statistic & - & 42.72 & - & 37.15 \\
\hline \multirow{2}{*}{\multicolumn{2}{|c|}{ D. Log of Female Immigrant Share }} & $-0.02 *$ & $-0.06 * * *$ & $-0.03 * * *$ & $-0.04 * * *$ \\
\hline & & $(-1.88)$ & $(-5.43)$ & $(-3.18)$ & $(-4.25)$ \\
\hline \multirow[t]{3}{*}{ First Stage: } & Instrument & - & $0.46 * *$ & - & $0.47^{* *}$ \\
\hline & T-statistic & - & $(2.80)$ & - & $(2.72)$ \\
\hline & F-statistic & - & 34.75 & - & 30.92 \\
\hline \multicolumn{2}{|l|}{ Observations } & 252 & 252 & 252 & 252 \\
\hline
\end{tabular}

Key. $* * *, * *, *$ denote statistical significance from zero at the $1 \%, 5 \%, 10 \%$ significance level. T-statistics are indicated in parentheses below the point estimate.

Notes. The dependent variable is the relative log mean wage of native women. In Panel A, the explanatory variable is the ratio between the relative number of female immigrants (as compared to female natives) and the relative number of male immigrants (as compared to male natives) in each cell. In Panel B, the explanatory variable is the relative number of immigrant women as compared to immigrant men. In Panel C, we take the log of the female/male immigrant ratio. In Panel D, the explanatory variable is the log share of immigrant women. In this table, we focus our attention on full-time workers only. All regressions include education, experience, and time fixed effects, as well as interactions between education and experience fixed effects, education and time fixed effects, and experience and time fixed effects. The standard errors are adjusted for clustering at the education and experience level. 
Table 7: The Long-term Effects of Immigration on Native Wages by Gender and Education

\begin{tabular}{ccccccc}
\hline \hline & $(1)$ & $(2)$ & $(3)$ & $(4)$ & $(5)$ & $(6)$ \\
\cline { 2 - 6 } & \multicolumn{7}{c}{ Set of Parameter Values } \\
\hline$\sigma_{H L}$ & 4 & 2 & 4 & 2 & 4 & 4 \\
$\sigma_{L}$ & 10 & 20 & 10 & 20 & 10 & 10 \\
$\sigma_{X}$ & 7 & 7 & 7 & 7 & 7 & 7 \\
$\sigma_{F}$ & 12.5 & 12.5 & 12.5 & 12.5 & 5 & $\infty$ \\
$\sigma_{I}$ & $\infty$ & $\infty$ & 20 & 20 & $\infty$ & $\infty$ \\
\hline \hline
\end{tabular}

\section{Percentage Change of Native Wage due to Immigration}

\begin{tabular}{lcccccc}
\hline $\begin{array}{l}\text { Average Long-term Effects } \\
\text { Male }\end{array}$ & -0.01 & -0.01 & 0.08 & 0.08 & -0.01 & -0.01 \\
Female & 0.06 & 0.06 & 0.10 & 0.11 & 0.16 & -0.01 \\
\hline Highly Educated & -0.11 & -0.13 & 0.04 & 0.03 & -0.28 & 0.00 \\
$\quad$ Male & -0.57 & -1.14 & -0.37 & -0.95 & -0.57 & -0.57 \\
$\quad$ Female & -0.49 & -1.06 & -0.34 & -0.92 & -0.36 & -0.57 \\
Medium Educated & -0.69 & -1.26 & -0.42 & -0.99 & -0.88 & -0.56 \\
$\quad$ Male & 0.10 & 0.35 & 0.20 & 0.44 & 0.10 & 0.10 \\
$\quad$ Female & 0.17 & 0.42 & 0.22 & 0.46 & 0.30 & 0.08 \\
Low Educated & -0.01 & 0.23 & 0.16 & 0.41 & -0.25 & 0.14 \\
Male & 0.33 & 0.46 & 0.31 & 0.44 & 0.33 & 0.33 \\
Female & 0.35 & 0.48 & 0.32 & 0.45 & 0.37 & 0.33 \\
\hline \hline
\end{tabular}

Notes. The table reports the simulated effects of immigration on the wages of native workers by education and gender. Each number stands for the percentage wage changes due to immigrants for natives. All simulations assume $\sigma_{X}=7$. While the left-hand side of the table assumes $\sigma_{F}=12.5$, the right-hand side assumes alternative values for $\sigma_{F}$. We test the robustness of our results by using different substitution elasticity values between education groups, and between natives and immigrants. The total wage effect is computed as the sum of direct effects due to immigration and indirect effects due to employment responses. 
Table 8: The Long-run Effects of Immigration by Gender under Rigid/Perfect Labor Market

\begin{tabular}{|c|c|c|c|c|c|c|}
\hline & (1) & (2) & (3) & (4) & (5) & $(6)$ \\
\hline & \multicolumn{6}{|c|}{ Set of Parameter Values } \\
\hline$\sigma_{H L}$ & 4 & 4 & 4 & 4 & 4 & 4 \\
\hline$\sigma_{L}$ & 10 & 10 & 10 & 10 & 10 & 10 \\
\hline$\sigma_{X}$ & 7 & 7 & 7 & 7 & 7 & 7 \\
\hline$\sigma_{F}$ & 5 & 12.5 & 12.5 & 5 & 12.5 & 12.5 \\
\hline \multirow[t]{2}{*}{$\sigma_{I}$} & $\infty$ & $\infty$ & 20 & $\infty$ & $\infty$ & 20 \\
\hline & \multicolumn{3}{|c|}{ Rigid Labor Market } & \multicolumn{3}{|c|}{ Perfect Labor Market } \\
\hline Average Wage Effect & -0.01 & -0.01 & 0.08 & -0.02 & -0.02 & 0.26 \\
\hline Male $(a)$ & 0.16 & 0.06 & 0.10 & 0.32 & 0.12 & 0.31 \\
\hline Female $(b)$ & -0.28 & -0.11 & 0.04 & -0.61 & -0.25 & 0.17 \\
\hline Differences $(a-b)$ & 0.44 & 0.17 & 0.06 & 0.93 & 0.37 & 0.18 \\
\hline
\end{tabular}

Notes. The table reports the long-run simulated effects of immigration on native wages by gender according to whether wages are rigid or perfectly flexible. Each number stands for the percentage wage changes due to immigrants for natives. We use $\sigma_{H L}=4$, $\sigma_{L}=10, \sigma_{X}=7$ and different values for $\sigma_{I}$ and $\sigma_{F}$. On the left-hand side, the total wage effect is computed as the sum of direct effects due to immigration and indirect effects due to employment responses. 